

\section{Article Artículo Paper Estratègies, plataformes i dispositius que afavoreixin la participació dels joves}

\section{Íngrid Pujol ${ }^{1}$}

1. Educadora social

\section{Resum}

La participació és un dret, però no tothom es troba en les mateixes condicions per a poder exercir-lo. És aleshores quan cal que sapiguem treballar per a fomentar la participació i capacitem les persones a que puguin decidir sobre allò que passa al seu voltant, actuïn en funció de les seves necessitats, puguin intervenir en el seu entorn $\mathrm{i}$ aprenguin a responsabilitzar-se i organitzar-se en comunitat. A partir de la seva experiència com a dinamitzadora del Kasal de Joves Roquetes, situat al districte de Nou Barris (Barcelona) l'autora reflexiona sobre la participació dels joves i sobre el treballar amb joves a través de la participació, com una oportunitat aprendre a conviure amb la diversitat i fer front a les desigualtats. A banda de posar en valor el coneixement del territori a l'hora d'impulsar qualsevol projecte de participació, l'autora destaca les 5 qüestions a tenir presents perquè el procés de participació tingui sentit i arribi a bon port: el què, el qui, l’on, el quan, el com i el per què de la participació. Finalment fa referència a dues experiències d'interès $i$ a alguns recursos a tenir en compte. 
Paraules clau: participació, joves, procés de treball, acompanyament educatiu

\begin{abstract}
Participation is a right, but not everyone is in the same condition to be able to exercise it. It is then that we need to know how to work to encourage participation and train people to be able to decide on what is happening around them, act according to their needs, be able to intervene in their environment and learn to take responsibility and organize. in the community. Based on her experience as a facilitator of the Kasal de Joves Roquetes, located in the Nou Barris district (Barcelona), the author reflects on the participation of young people and on working with young people through participation, as an opportunity to learn to coexisting with diversity and tackling inequalities. In addition to highlighting the knowledge of the territory when promoting any participation project, the author highlights the 5 issues to keep in mind so that the participation process makes sense and comes to fruition: what, who, where, when, how and why of participation. Finally, it refers to two experiences of interest and some resources to consider.
\end{abstract}

Key words: participation, youth, work process, educational support 


\section{Justificació}

La participació és un dret de la ciutadania que no només s'exerceix cada cop que hi ha eleccions sinó que ha d'anar més enllà; no pot excloure persones en funció de si tenim o no tenim una situació regularitzada; o bé, en funció dels nostres recursos econòmics. Davant les desigualtats, en general, es tendeix a generar actituds, projectes o recursos assistencials, que en algunes ocasions són necessàries. Però a vegades cal anar més enllà, i treballar en clau de participació pot afavorir-ho.

Entenem participació com una eina per capacitar a una persona a decidir sobre allò que passa al seu voltant, sobre les seves necessitats i les del seu entorn com també aprendre a responsabilitzar-se i organitzar-se en comunitat. Els processos en clau de participació poden semblar lents $i$ potser no es veuran resultats de manera ràpida però poden influenciar en el futur de les persones i el seu entorn social. Per això, la participació necessita d'actituds, predisposició, projectes i recursos a curt, mitjà i llarg termini.

Treballar a través de la participació amb joves és una oportunitat també per treballar la diversitat i la convivència, com també a la inversa. Valgui la redundància, la realitat social que ens envolta és diversa. A la majoria de pobles, ciutats i barris hi ha persones de diferents gèneres, edats, orígens i un llarg etcètera. Generalment, aquestes diferències generen desigualtats socials, econòmiques o culturals. Treballar a través de la participació ha de ser un mecanisme per eradicar aquestes desigualtats i transformar l'entorn que ens envolta.

Treballar amb joves a través de la participació també és un repte. Ens afrontem a prejudicis propis que a vegades desconeixem, a buscar solucions per a l'entesa, a pal-liar problemes d'intraracisme, i a entendre que participar no ha de ser integrar. Les realitats culturals que ens envolten a vegades xoquen amb la nostra i pot suposar també produir canvis en les nostres pròpies dinàmiques. Potser s'ha de pensar en quina hora va bé quedar, si el lloc és l'adequat, si podran venir dones i homes per igual, etc. Si hi ha alguna resposta que trontolla, potser hem de donar-hi alguna volta més.

La participació necessita de la comunitat i del territori que l'envolta. És per això necessari conèixer bé el territori on ens movem, si ja hi ha dinàmiques o canals de participació, quin tipus de teixit associatiu tenim, etc. I a partir d'aquí, comencem recordant 
que treballar a través de la participació no s'ha d'entendre com una obligació sinó com una oportunitat. A vegades, però, cal tenir l'experiència, per veure'n la importància perquè la participació és un aprenentatge per a tothom que cal anar treballant a poc a poc i ampliant el coneixement, la responsabilitat, l'organització i el bé comú a través de la vivència.

\section{Descripció de la proposta}

De cara a plantejar-nos un projecte o una acció de participació juvenil, hem de tenir en compte diferents factors i plantejar-nos vàries preguntes per tal de donar contingut al projecte. Es podrien resumir en 5 preguntes bàsiques: què, qui, on, quan, com i per què.

\subsection{Què?}

El què és l'acció, projecte o activitat que volem portar a terme. A vegades, aquesta proposta pot venir donada per l'equip tècnic. Però pot ser molt interessant que aquesta idea surti de les mateixes joves. Si és així, s'afavoreix que aquesta proposta pugui tirar endavant de manera participada durant tot el procés. Per això és important preguntar a les joves i anar coneixent què volen o què necessiten.

Quan pensem en el què, també vol dir pensar en els objectius de la intervenció o projecte i el que pretenem aconseguir. Els objectius han de ser clars, factibles i les persones que hi participaran els han de conèixer i/o proposar-los.

\subsection{Qui?}

Hem de saber amb qui volem treballar: amb tota la comunitat jove, amb un grup estable, un grup nou, etc. Hi ha infinitat de possibilitats però hem de poder definir el qui i de passada pensar si el grup o comunitat amb qui volem treballar representa la diversitat que hi ha al territori en termes de gènere, origen, cultura, religió, etc. Com també saber si és per només persones joves o bé es vol treballar algun projecte intergeneracional. 
En tots aquests casos, hem de tenir present que els graus de coneixement, de participació, de responsabilitat i d'organització són diferents en funció de cada persona i ho haurem de tenir en compte en la planificació i durant el procés.

\subsection{On?}

Per un projecte o acció participada hem de conèixer el territori on treballem i fer-nos algunes preguntes més: com és el teixit social del barri o poble? És participatiu? Tenim alguna xarxa o bé entitats, associacions o agents que treballin amb aspectes similars als nostres? Hi podem crear aliances? Totes aquestes preguntes ens poden servir per enxarxar-nos i evitar repetir processos similars que hagin pogut engegar des d'altres serveis o entitats.

D’altra banda, i en un nivell més específic de cara al treball amb joves, també hem de conèixer per on es mouen o bé si tenen un espai propi per desenvolupar les seves activitats o inquietuds (equipament municipal, local d'entitat, medi obert, etc). Aquests llocs són espais de trobada a tenir en compte per tal d'afavorir un vincle amb les joves o enganxar-los al projecte. No podem esperar que les joves apareguin a un espai que determinem nosaltres si prèviament no el coneixen o no hi tenen relació.

\subsection{Quan?}

El projecte o activitat, per petita que sigui, s'ha de planificar en totes les seves etapes. És un procés que es pot compartir amb les joves. Les etapes les podem dividir en tres parts: la planificació, l'execució i l'avaluació.

1. La primera serveix per compartir els objectius i calendaritzar quan portarem a terme l'acció o activitat. Aquí també s'organitza tota la prèvia a l'acció, és a dir, les trobades de preparació, l'organització, la definició de tasques i el seu repartiment.

2. L'etapa d'execució és el moment que es produeix l'acció, activitat o projecte, on cada persona fa el què s'ha acordat. Per últim, i important, l'avaluació. Un cop passada l'acció o activitat, les persones que han participat de l'acció s'han de poder trobar per valorar com ha anat, què ha funcionat i què no, què es pot millorar $i$ com els hi agradaria seguir. 


\subsection{Com?}

Aquí ens hem de plantejar la metodologia i la dinamització que farem de tot el procés participatiu. Un dels punts és conèixer quin grau de vincle tenim amb les joves $\mathrm{i}$ treballar-lo a través d'espais de trobada més o menys informals. Treballar la motivació en el grup és fonamental per a mantenir el procés.

Tot i així, abans de començar a treballar, ens hem de plantejar si ens creiem la participació, és a dir, la nostra convicció com a professional en què allò pot tirar endavant i que podem disposar o buscar els recursos humans, materials o econòmics necessaris.

D'altra banda, també és convenient determinar com serà el nostre rol d'acompanyament, de dinamització i de facilitació durant tot el procés. Segurament, haurem d'assumir una part important de responsabilitat i organització durant el procés participatiu. Però també haurem de saber ser una persona més dins del grup coneixent el poder i el rang que ens atorga el fet de ser professional, persona adulta i amb altres coneixements i informació.

\subsection{Per què?}

Ja per últim, ens hem de preguntar per què ho fem, per què portem a terme aquest procés participatiu i per què volem treballar d'aquesta manera. Cal tenir en compte, que a vegades podem tenir la pressió de treballar de manera pseudoparticipativa, és a dir, algunes iniciatives a vegades només volen rendir comptes amb la societat per validar el què s'està fent. Això no és participació. Potser també ens hem trobat que hi ha certa obligatorietat en tirar endavant algun procés participatiu amb un grup, quan aquest grup juvenil no en té la necessitat ni la motivació.

Per això, és important demanar-nos per què ho volem fer: treballar en clau de participació és un procés d'aprenentatge per a tothom, tant per a les professionals com per a les joves, i moltes vegades no tindrem resultats a curt ni mitjà termini. No naixem ensenyats ni ensenyades en el món de la participació i sovint hem de començar per petits objectius, petites accions que impulsin un procés que pugui arribar més lluny. 


\section{Experiències o models}

\section{Federació de Casals de Joves de Catalunya}

Descripció: Associació que agrupa associacions juvenils que fomenten la participació dels i les joves, des de la pròpia organització i sota el principis d'autogestió, democràcia, laïcitat i transformació social.

Enllaç: http://espai.casaldejoves.org/qui-som/

Recursos: Van publicar un llibre sobre el projecte educatiu dels casals que es diu Aixequem la persiana. Es pot consultar aquí: http://espai.casaldejoves.org/recurs/aixequem-la-persiana-projecte-educatiu-de-casals-de-joves-de-catalunya/

\section{Ciutat Esperança}

Descripció: Aquest projecte de l'Associació Cultural El Parlante es basa en la comunicació audiovisual, l'educació i la sensibilització per promoure una mirada crítica entre joves i reflexionar sobre la complexitat de les diferents realitats del barri de Ciutat Meridiana de Barcelona posant en valor la diversitat cultural i social. La mateixa entitat té més projectes en aquesta línia.

Enllaç: https://ciutat-esperanca.elparlante.es/ca/

\section{Altres recursos generals sobre participació juvenil}

\section{Guia Jove}

Descripció: La Guia Jove és una caixa d'eines per als i les professionals que treballen amb gent jove per fomentar la participació a través de la dinamització juvenil. Està formada per un conjunt de fitxes per facilitar possibles línies de treball segons les necessitats o els reptes que es persegueixen. El contingut de la Guia inclou temàtiques relaciona- 
des amb la participació juvenil, la planificació de projectes socioeducatius i l'ús dels espais d'intervenció, com ara equipaments o espai públic.

Enllaç: https://ca.wikibooks.org/wiki/Guia_Jove 
Xedagogia i Treball Social

Revista de Ciències Socials Aplicades

Edita: Universitat de Girona

Disseny i maquetació: info@clam.cat · 647427732

Dipòsit Legal: GI.904-2010

ISSN: 2013-9063 